\title{
TRADE GLOBALIZATION AND ITS IMPACT ON WELFARE IN INDONESIA
}

\author{
Yulinda Nurul Aini, Yanti Astrelina Purba, and Ruth Meilianna \\ Research Center for Population, \\ Indonesian Institute of Science, Jakarta, Indonesia \\ Corresponding Author Email: yulindaaini@gmail.com
}

\begin{abstract}
Indonesia was experiencing trade globalization in the form of decreasing and uniforming tariffs and eliminating various non-tariff barriers. Trade globalization had a positive and negative impacts on Indonesian's welfare. Therefore, this study aims to analyze the effect of Trade's Globalization on Indonesian's Welfare. The Trade globalization was measured by three variables, namely Trade Openness, Inflation, and Exchange Rate. While Indonesian's Welfare was measured by three aspects, namely education aspect using School Enrollment, health aspect using Life Expectancy, and economic aspect using the GDP Per capita. The data used was time series data from I97I-20I6. This study applied mix-methods, quantitatively using Structural Equation Modeling Partial Least Square (SEM-PLS) and qualitatively using desk study. The results indicated that Trade Openness and Exchange Rate were positive and significant indicators in measuring Trade globalization. In addition, School Enrollment and GDP Per capita were also positive and significant indicators in measuring Indonesian's Welfare. In general, the test showed that Trade globalization had a negative and significant influence on Indonesian's Welfare. This fact suggested the importance of controlling exchange rate stability in Indonesia, because exchange rate could affect people's ability to maintain lives through purchasing power. In addition, globalization measured through Trade Openness could be an accommodation to obtain new technology in various fields, such as in education to improve the quality of human resources, in health sector to treat various diseases and reduce the risk of death, and in economy sector to increase Per capita income.
\end{abstract}

Keywords : globalization, trade sector, SEM-PLS, welfare level.

\begin{abstract}
Abstrak
Indonesia sedang mengalami globalisasi perdagangan berupa penurunan dan penyeragaman tarif serta penghapusan berbagai hambatan non tarif. Globalisasi perdagangan menimbulkan dampak positif maupun negatif bagi kesejahteraan Indonesia. Karena itu, penelitian ini bertujuan untuk menganalisis pengaruh Globalisasi Perdagangan yang diproksi menggunakan variabel Trade Openness, Inflasi, dan Kurs, terhadap Tingkat Kesejahteraan yang diukur berdasarkan 3 aspek, yaitu aspek pendidikan menggunakan indikator Angka Melek Huruf, aspek kesehatan menggunakan indikator Angka Harapan Hidup, dan aspek kehidupan yang layak menggunakan indikator GDP perkapita. Data sekunder yang digunakan beruapa data time series tahun I97I-20I6. Penelitian menggunakan mixmethode, secara kuantitatif menggunakan Structural Equation Modelling Partial Least Square (SEM-PLS). Hasil penelitian menunjukkan bahwa Trade Openness dan Kurs merupakan indikator yang positif dan signifikan dalam mengukur Globalisasi Perdagangan. Selain itu, School Enrollment dan GDP Perkapita juga menjadi indikator yang positif dan signifikan dalam mengukur Kesejahteraan Negara. Secara umum, pengujian memberikan hasil bahwa Globalisasi Perdagangan memberikan pengaruh negatif dan signifikan terhadap Kesejahteraan Negara. Fakta ini menyarankan pentingnya pengendalian stabilitas kurs di Indonesia, mengingat kurs dapat mempengaruhi kemampuan masyarakat dalam mempertahankan hidupnya melalui daya beli. Selain itu, globalisasi yang diukur melalui Trade Openness dapat menjadi akomodasi untuk memperoleh teknologi baru dari luar negeri di
\end{abstract}


berbagai bidang, seperti bidang pendidikan untuk meningkatkan kualitas sumber daya manusia, bidang kesehatan untuk mengobati berbagai penyakit dan menurunkan resiko kematian, serta bidang ekonomi untuk meningkatkan pendapatan perkapita masyarakat.

Kata kunci: Globalisasi, Setor Perdagangan, SEM-PLS, Tingkat Kesejahteraan.

\section{INTRODUCTION}

Welfare is the main goal of Indonesia's development. Various policies were created to achieve the main objectives of Indonesia's welfare. The quality of human life in a country could be measure as prosperity or not. The quality of human life could be seen by various tools such as the level of health, education and society's income. The increase in GDP Per capita, School Enrollment and Life Expectancy indicated that the society's welfare was increased. This welfare improvement was one of the effects of globalization in Indonesia (Soediro, 20I7).

The impact of globalization was that the economy of a country would have an influence on the economy of other countries as a trade partnerships. It occured in trade globalization as well, of which could affect the Indonesian's welfare. The existence of trade globalization had become an important aspect in state's economic throughout the world, hence a balance of goods supply and demand would be achieved in all countries.

In the past 50 years, international trade had grown and developed drastically and in large measure. It was due to cooperation carried out by various countries to eliminate trade protection and the desire to promote trade in goods and services freely. It would also related to the globalization of economic where there was a process of integration between countries in economic and trade activities. Countries in one region would have market power without obstacles and distance between countries. If economic globalization occurs, then the boundaries of a country would decreases and the linkages between the national and international economy would be even tighter.

Trade globalization has been led by reduction and uniformity of tariffs and the elimination of various non-tariff barriers. Thus trading activities became more stringent and fair (Firmansyah,2005). For Indonesia, the elimination of tariffs could have a positive or negative impact. With the reduction and uniformity of tariffs, export and import activities became easier and cheaper but this also made Indonesia have to face new competition from developed countries that are able to produce products with good quality and competitive prices. These changes had an impact on the economy, education, and health of society.

It was considered as an ongoing debate regarding the impact of globalization on trade. Wijaya and Sambodo (2006) stated that economic openness can be a stimulator to drive the economy more. After the enactment of trade openness and financial openness policies in countries around the world, the growth of world trade rosed more than threefold in the period from I980 to 2002. Openness has led developing countries to fantastic economic growth (Diputra, 2017), but besides that, empirical data showed that globalization tends to enrich developed countries, where those countries had mastered strategic economic resources such as capital, technology and information.

According to experts, globalization could provide benefits for both developed and developing countries if managed properly, one of that was by making appropriate policies to carry out globalization in accordance with the background of the traditions, culture, and history of a country. In addition, globalization could socially enhance the unity of humanity through cooperation, sharing knowledge, expertise and resources. But in its implementation, not all countries had benefit equally from globalization activities, especially in low income countries. Therefore, globalization needed to be directed at equitable growth and prosperity through social and political integration to improve the economy and progress of the country. 
Globalization would create competition. According to Krugman and Obstfeld (2004) in Pasaribu (20I7), trade globalization would benefit the owners of abundant production factors in a country, but the owners of scarce production factors in a country would suffer losses due to international trade.

In Indonesia, trade globalization was characterized by the joining of Indonesia in several international trade organizations, such as the ASEAN Free Trade Area (AFTA), the Asia Pacific Community (APEC) and several other organizations. The process of deepening the trade globalization created more open Indonesian trade. Based on World Bank data, throughout I97I-2016, there was an increase in trade openness in Indonesia. However, the activities of Indonesian in global market were still considered to be inadequate in driving the level of society's welfare.

There have been many studies discussing about the globalization of trade. Research conducted by Firmansyah and Hendra (2005) showed that free trade was a separate variant of international trade. Free trade was international trade without any barriers to entry such as tariffs, quotas, import duties, export duties, dumping and so on. This study, moreover, explains that economic globalization and free trade have implications for rupiah stability so that Bank Indonesia plays an important role as a monetary authority that has the goal of achieving and maintaining rupiah stability to be more alert, sensitive and have broad access to information on fluctuations in macroeconomic variables in real times.

As Amala and Heriqbaldi (2015) did in their research, the results showed that openness of international trade in service sector had a significant effect on economic growth in all countries, both in high, middle and low income countries. Moreover, The openness of sectoral service trade had a significant effect on economic growth in middle and low-income countries, but had no significant effect on highincome countries. Furthermore, the openness of trade in other business services sector had a significant effect on economic growth in all countries.
Research conducted by Nawatmi (20II) showed that Indonesia follows Global-Centric Approach (Globalization can affect domestic inflation). The estimation results using the ECM model showed that globalization has a negative effect on inflation in Indonesia in the long term. It showed that increasing globalization will reduce inflation in Indonesia in the long term, while in the short term globalization has no effect on inflation.

Research conducted by Borchert and Yotov (2017) showed that globalization can affect manufacturing trade in I986-2006 period and on average the impact has decreased by Io\% due to the impact of relations and regional trade agreements that increase over time. It was also known that globalization benefits most in middle-income countries. This was also in line with the research conducted by Aliyah and Indra (2017) which shows the impact of globalization on trade on the welfare level of Muslim countries. Based on estimation results, inflation and exchange rates had a significant effect on almost of all welfare indicators and indicate that globalization in general, which is reflected by Trade Openness, had an effect on the welfare of Muslim countries.

Globalization not only had an impact on trade but also on the education sector. It was supported by the research of Salim and Sari (20I4) which shows that technological progress due to the rapid flow of globalization will change the pattern of teaching in the world of education. Classical teaching method will turn into teaching based on new technologies such as computers. Globalization presented a challenge for the education sector to produce competitive and resilient human resources so that they can compete with the flow of globalization.

Previous studies have discussed a lot about trade globalization, but more on how it affects the macroeconomic variables, such as the effect of trade globalization on inflation, rupiah exchange rate stability, as well as economic growth in the low, medium and high income countries. In addition, other studies also discussed more about the implementation and impact of trade globalization in health, education, and economic aspects partially. Many researchs rarely 
addressed the influence of trade globalization in the society's welfare, which in this case is measured using health, education, and decent life indicators. In addition, many studies more often used qualitative methods in the form of desk studies that were not supported by statistical analysis, while this study used quantitative analysis methods, namely structural equation modeling partial least square (SEM-PLS) to find out the effect of trade globalization on society's welfare, which was also supported by literature review from previous studies. In this research, the Society's Welfare as a response variable was measured using variables of Life Expectancy, School Enrollment, and GDP Per capita, while the Trade Globalization as a predictor variable was measured using Trade Openness variable in I97I-2016.

\section{LITERATURE REVIEW}

\section{Economic and Trade Globalization}

Globalization was understood simply as the process of integrating national economic into a global economic system (Faikh, 2002). In contrast to Faikh (2002) and Suprijatno (20II) viewed globalization as a long phase of liberal capitalism development, which theoretically had been developed by Adam Smith.

Economic globalization refered to the increasing unity of world economic units into a unit of world economy (Pasaribu, 2013). Economic openness was divided into two types of openness, namely, trade openness and financial openness (Diputra, 2017). Trade Openness in terms of foreign trade illustrated that the diminishing trade barriers between countries and the increasing share of trade for domestic producers. Concrete manifestation of globalization in economic field occured in the following aspects such as aspects of production, finance, labor, network information, and trade aspects. The trade aspect was manifested in the form of decreasing and uniformity of tariffs and elimination of various non-tariff barriers (Pasaribu, 20I4). Therefore, trade activities and competition became increasingly fierce and fair.

Trade globalization is indicated by tremendous increase in global trade activities which then leads to interdependence of parts of global economy (Suprijatno, 20II). According to him, the economic development was due to tendency of specialization, the strength of competition between companies or between countries, as well as progress in transportation and communication lately. Fundamentally, globalization occurs when the enactment of a new global social formation marked by the implementation of global trade mechanism through the creation of a free trade policy.

Globalization entered all fields of life, one of which was in field of education which is characterized by rapidly developing science and technology. Therefore, the education sector needed to improve the management of education so that it is more productive and provides the widest possible access for society to obtain education, so that the quality of education could increase. The rapid flow of globalization had its own impact on education world, where in recent years many schools in Indonesia had begun to globalize the school's internal education system. Schools began to implement bilingual school. In addition, secondary and tertiary schools, both public and private, have opened international class programs. This is important considering that qualified graduates would become workers in Indonesia who can compete in the world market.

Based on these meanings, then in this study the intended trade globalization is the process of losing or reducing trade barriers in buying and selling transactions between countries. This can benefit a country yet can be detrimental to countries that cannot compete. Trade globalization can be measured based on trade openness, which is the proportion of all production across national borders.

\section{Trade Globalization and Society's Welfare}

Economic development was not only measured by economic growth but also an increase of society's welfare. Improving community welfare could be seen from the health and education of society. With the increase in these two factors, human resources could be more productive. It was reinforced by Diputra (20I7), aside from economic aspects, human development also 
covered various aspects such as social, political, cultural and other aspects to make people more productive in their activities. He stated that the development paradigm includes two sides, namely human capability information such as improving the level of health, education and skills. The other side was the use of their capabilities for productive, cultural, social and political activities. Good sources of economic growth with links to institution technology were determined by high levels of education and health. It was certainly in an effort to increase the level of society's welfare itself which leads to advanced economic activities. The ability of a developing country to absorb modern technology and develop capacity to create sustainable growth and development was largely determined by education. Besides health determines productivity nonetheless.

Weakening of the position of a country that lacks skills and capital, weak management in international trade, exploitation of workers, unstable global capital market risks, weakening national cultural stability, autonomy of the national economy damaged by openness in capital markets. The poorer ones had to accept policies made by richer countries which were negative impacts of globalization (Mutascu and Fleischer, 20II). Research by Chen and Ravallion (2007), Ravallion (2006), Abbott (2003), and Twyford (2003) found that poverty was still high along with the development of economic globalization and could exacerbate income inequality because the production process was divided and some parts were transferred abroad (Feenstra and Hanson, I999) and increase inequality (Cornia and Kiiski, 200I).

Globalization will have a positive impact on several countries but will also have a negative impact on some countries. Globalization will create competition. Pasaribu (2017), in accordance with Krugman and Obstfeld (2004) states that the owners of abundant production factors in the country will benefit from trade relations, but the owners of related production factors in countries will increase losses due to international trade. According to StoplerSamuelson's argument, trade openness will increase capital to increase money in abundance of capital and will reduce income inequality if the country is abundant in labor (Asteriou et al., 2013).

\section{RESEARCH METHODOLOGY}

\section{Data and Data Source}

The impact of trade globalization on society's welfare would be seen based on several indicators, because each variable was latent which can't be measured directly, it required indicators which could measure these variables. The Trade globalization as an predictor variable would be proxied using the indicator of Trade Openness in Indonesia. While the level of Indonesian Welfare would be measured based on 3 aspects, namely the education aspect by using indicator of School Enrollment, health aspect using indicator of Life Expectancy, and decent life aspect using GDP Per capita. The data used was time series data from I97I-20I6 obtained from several sources with the following information.

Table I Data and Data Source

\begin{tabular}{|c|c|c|c|c|}
\hline $\begin{array}{l}\text { Latent } \\
\text { Vari- } \\
\text { able }\end{array}$ & Indicator & Source & Unit & $\begin{array}{l}\text { Type/ } \\
\text { Data Scale }\end{array}$ \\
\hline \multirow{3}{*}{$\begin{array}{l}\text { Global- } \\
\text { ization } \\
\text { of Trade }\end{array}$} & $\begin{array}{l}\text { Trade Open- } \\
\text { ness }\end{array}$ & World Bank & $\%$ GDP & $\begin{array}{l}\text { Numeric/ } \\
\text { Ratio }\end{array}$ \\
\hline & Inflation & World Bank & $\%$ Yearly & $\begin{array}{l}\text { Numeric/ } \\
\text { Ratio }\end{array}$ \\
\hline & $\begin{array}{l}\text { Exchange } \\
\text { Rate }\end{array}$ & World Bank & $\begin{array}{l}\text { LCU per } \\
\text { US\$ }\end{array}$ & $\begin{array}{l}\text { Numeric/ } \\
\text { Ratio }\end{array}$ \\
\hline \multirow{3}{*}{$\begin{array}{l}\text { Welfare } \\
\text { of Soci- } \\
\text { ety }\end{array}$} & $\begin{array}{l}\text { Life Expec- } \\
\text { tancy }\end{array}$ & World Bank & Year & $\begin{array}{l}\text { Numeric/ } \\
\text { Ratio }\end{array}$ \\
\hline & $\begin{array}{l}\text { School } \\
\text { Enrollment } \\
\text { Tertiery }\end{array}$ & World Bank & $\%$ Gross & $\begin{array}{l}\text { Numeric/ } \\
\text { Ratio }\end{array}$ \\
\hline & $\begin{array}{l}\text { Constant } \\
\text { GDP Per } \\
\text { capita } 2000\end{array}$ & World Bank & Rupiah & $\begin{array}{l}\text { Numeric/ } \\
\text { Ratio }\end{array}$ \\
\hline
\end{tabular}

Based on parameter estimation process, this method was divided into covariant-based SEM (CB-SEM) and SEM-based variance, one of which was Partial Least Square (PLS). PLS was classified as soft modeling because it eliminates OLS (Ordinary Least Square) regression assumptions, as data must be normally distributed in a multivariate distribution and there were no multicolinearity problems between variables. 
Since the PLS algorithm used series ordinary least square analysis, identification of model was not a problem in recursive model and also did not assume a particular form of distribution. Furthermore, the algorithm in PLS was able to estimate large and complex models with hundreds of latent variables and thousands of indicators. However, the PLS method also had disadvantages, such as the distribution of unknown data so that it could not assess statistical significance. This weakness could be overcome using the resampling bootstrap method (Ghozali \& Fuad, 2005).

\section{Technique of Data Analysis}

The data analysis technique in this study applied quantitative method. Quantitative data analysis was conducted to determine the effect of trade globalization on society's welfare using Structural Equation Modeling Partial Least Square (SEM-PLS) method. According to Wijayanto (2008), SEM was a development method of multivariate analysis which stems from factor, principal component, covariance, and correlation analysis. SEM had the ability to solve problems involving many linear equations by producing measurement models as well as structural models. In addition, the SEM method was more focused on whether or not the theories in building hypotheses are proven, not on the model formed.

Based on parameter estimation process, this method was divided into covariant-based SEM (CB-SEM) and SEM-based variance, one of which was Partial Least Square (PLS). PLS was classified as soft modeling because it eliminates OLS (Ordinary Least Square) regression assumptions, as data must be normally distributed in a multivariate distribution and there were no multicolinearity problems between variables. Since the PLS algorithm used series ordinary least square analysis, identification of model was not a problem in recursive model and also did not assume a particular form of distribution. Furthermore, the algorithm in PLS was able to estimate large and complex models with hundreds of latent variables and thousands of indicators. However, the PLS method also had disadvantages, such as the distribution of unknown data so that it could not assess statistical significance. This weakness could be overcome using the resampling bootstrap method (Ghozali \& Fuad, 2005). In general, procedures were used through several stages, including the following.

I. Developed a theory-based conceptual model.

In this stage, there were two models that will be designed, namely the measurement model (outer model) which connected indicators and latent variables, includes the reflective/ formative model and the inner model which described the relationship between constructs (latent variables).

2. Established a construct of path diagram

3. Converted a path diagram into a system of equations, which includes the inner model and outer model.

The outer model aimed to measure the dimensions which form a factor and model which represents the pre-existing hypotheses and evaluated using Confirmatory Factor Analysis (CFA). The equation matrix is as follows.

$$
\mathbf{A}_{p x 1)} \xi_{\mathbf{x}(p x n)} \boldsymbol{\xi}_{(n x 1)}+{ }_{(p x 1)}
$$

which is,

x : Indicator of exogenous/endogenous latent variables

$\Lambda x$ : loading matrix which describes the relationship between indicators and exogenous/ endogenous variables

$\xi \quad$ : vector of exogenous/endogenous latent variables

$\delta$ :measurement error vector of indicators on the exogenous /endogenous variable

Inner PLS models were designed for recursive models, which were models that describe the causal relationship between exogenous and endogenous latent variables. The following is the inner model equation.

$$
\eta_{j}=\sum_{i=1}^{I} \beta_{j i} \eta_{i}+\sum_{h=1}^{H} \gamma_{j h} \xi_{h}+\zeta_{j}
$$

which is,

$\eta \quad$ : endogenous latent variables, $j=1,2, \ldots, \mathrm{k}$ 
$\beta \quad$ : coefficient of endogenous latent variables

$\gamma \quad$ : path coefficient that connects exogenous and endogenous latent variables

$\xi \quad$ : endogenous latent variables, $\mathrm{j}=1,2, \ldots, \mathrm{k}$

$\zeta \quad$ : structural measurement error

4. Estimated parameters of inner and outer model.

The estimation started with the initialization of each latent variable as a linear combination with weights to estimate scores of latent variables with variance indicators and constructs. Then iterated until it reaches convergence.

5. Evaluated the measurement model by testing the validity and reliability test.

Validity test used the value of convergent validity to measure the magnitude of correlation between latent variables and indicators. The indicator was said to be valid if value of the standardize loading factor $(\lambda)$ was above 0.5 .

6. Evaluated the structural model by looking at $\mathrm{R}^{2}$.

This value indicated the variability magnitude of endogenous variables that could be explained by exogenous variables. Chin (I998) explained the limitation criteria for $\mathrm{R}^{2}$ values in three classifications, namely substantial $\mathrm{R}^{2}$ (>0.67), moderate (0.33-0.66), and weak (<0.33).

7. Performed hypothesis testing using bootstrap resampling.

Bootstrap created pseudo data using information from the original data by paying attention to the properties of original data, so that pseudo data had characteristics similar to the original data. This stage was used in calculating statistic test with the following hypothesis.

$\mathrm{H}_{0}: \lambda_{i}=0$ (the-i parameter is not significant)

$\mathrm{H}_{1}: \lambda_{i} \neq 0$ (the-i parameter is significant))

Test of Statistics :

$$
t_{\text {hitung }}=\frac{\hat{\lambda}_{i}}{S E\left(\hat{\lambda}_{i}\right)}
$$

To obtain a decision, the value of $t_{\text {hitung }}$ compared with $t_{\text {tabel }}$ at $\alpha$ significant level. If the value of $t_{\text {hitung }}>t_{\text {tabel }}$, then the indicator was said to be valid and could measure latent variables.

\section{RESULT AND DISCUSSION}

\section{Indonesia's Participation In Trade Global- ization}

Indonesia used a mixed economic system such as that used by Germany and Japan where the country unites and directs the newly emerging liberal economy through protection and subsidies (Deliarnov, 2012). The wave of globalization increased in the I980s, both in terms of intensity and coverage. Beginning in the mid 9os, Indonesia increasingly gave a role to the market and reduced government interference through debureaucratization and deregulation (Diputra, 20I7). Globalization of Indonesian Trade began when Indonesia joined the Asia-Pacific Economic Cooperation (APEC) in I989. APEC was the economic forum for $2 \mathrm{I}$ countries in the Pacific Rim. The aim of APEC is to increase economic growth, strengthen the community and encourage free trade throughout the Asia-Pacific region. APEC was created due to the economic interdependence of the Asia-Pacific countries and the birth of other trade blocs in other parts of the world. APEC has 22 member countries.

In 2004, there was an agreement to conduct a feasibility study (Feasibility study) for the establishment of the Free Trade AgreementAsia Pacific (FTA-AP). The purpose is to analyze the impact of the FTA-AP for Indonesia and analyze the determinants of the export performance of Indonesia's superior products. Simulation results show that a 50\% deduction has an impact on improving the welfare of all countries in AP-FTAs except the United States and if full liberalization is carried out, welfare improvements occur in all countries except Peru and rest of the world (ROW). In this case, when there is full liberalization, it will have an impact on improving welfare. This welfare increase can be made possible by trade diversion from the trade in FTA-AP. Welfare increases because the decrease in trade barriers in the form of tariffs will reduce production costs (production 
costs). Not only that, when the simulation is full of liberalization, Indonesia's trade balance has increased (Pusat Kebijakan Kerjasama Perdagangan Internasional, 20I5).

Figure I The Participation of Indonesia in Trade Globalization
Indonesia participated in the World Trade Organization (WTO) in I994 as well. The WTO is an organization that regulates international trade. The WTO was formed to replace GATT in I995. The number of WTO members is I6I member countries. All WTO member countries were required to give each other the status of

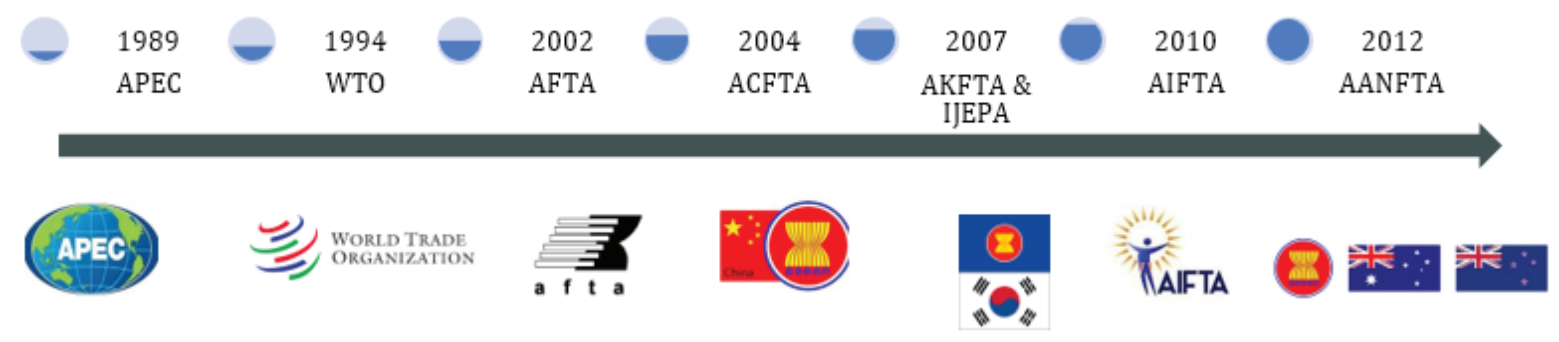

the most favored country so that the benefits given to a WTO member to another country must be given to all WTO members. In addition, Indonesia also participated in ASEAN Free Trade Area (AFTA) in 2002. AFTA was formed by ASEAN countries to create a free trade zone to increase the economic competitiveness of the ASEAN region. The number of AFTA members is Io people. ASEAN-China Free Trade Area (ACTFA) in 2004. ACFTA is a free trade area between members of ASEAN and CHINA. The agreement between the ACFTA was to allow the opening of Mandiri Bank branches and loans to LPEI and to open export credit facilities for infrastructure development in Indonesia. ASEAN Korea Trade Area (AKFTA) in 2007.

AKFTA is an agreement between ASEAN member countries and South Korea to create free trade areas by eliminating or reducing trade barriers both tariffs and non-tariffs, increasing market access services, regulations and investment provisions, as well as improving aspects of economic cooperation to encourage economic relations the AKFTA parties in order to improve the welfare of ASEAN people and South Korea. The AKFTA trade agreement covered not only trade agreements for reducing or eliminating tariffs but also related to rules of origin (ROO), modification of commitments, non-tariff policies, non-tariff protection and elimination policies based on the WTO. AKFTA was formed by ASEAN and the South Korean Government.

In addition, Indonesia participated in Indonesia-Japan Economic Partnership in
2007 which was an agreement on trade and investment cooperation. With the existence of the IJEPA, economic relations had been formed through bilateral cooperation in increasing the capacity for liberalization both in services and in the fields of goods, promotion and trade facilities, and investment between the two countries. Furthermore, IJEPA would accommodate a number of projects to improve Indonesia's product competitiveness in the fields of industry, agriculture, and forestry including joint initiatives to promote the manufacturing industry. Indonesia also participated in ASEAN-India Free Trade Area (AIFTA) in 20I0. AIFTA is expected to improve trade relations between ASEAN and India. Both of them agreed to target the bilateral trade value of the two arag countries to break the 2 digit number or US \$ Io billion in 20I0. AIFTA is expected to provide greater opportunities for Indonesia to increase exports to India. According to the Minister of Trade, AIFTA would open opportunities for increasing Indonesia's exports especially for commodities such as vegetables, fruits, fats, vegetable oils, chocolates, fertilizers, tanned materials and dyes, plastics, rubber products, leather products, paper, textiles, and coal, copper beans, glass, tools, automotive machinery, etc. In addition, Indonesia also follows ASEAN, Australia-New Zealand Free Trade Area (AANFTA) in 2012 (Center for Regional and Bilateral Policy, 20I3). AANZFTA is an agreement between the first free trade in which Australia included an article on Economic Cooperation. In reaching this 
agreement, Australia has also committed to special cooperation to meet Indonesia's needs.

\section{Descriptive Statistical Analysis of Research Data}

The following is a graph that shows the characteristics of the research data.

Figure 2 Society's Welfare Indicators

(a) School Enrollment Tertiary (b) GDP Per capita (c) Life Expectancy

Based on Figure 2a, it can be seen that the School Enrollment Tertiary in Indonesia from I97I-20I6 increased from $3 \%$ to more than $20 \%$ in 2016 . It showed that the number of high school students entering tertiary institutions was experiencing a significant increase. Furthermore, Figure $2 \mathrm{~b}$ shows the GDP Per

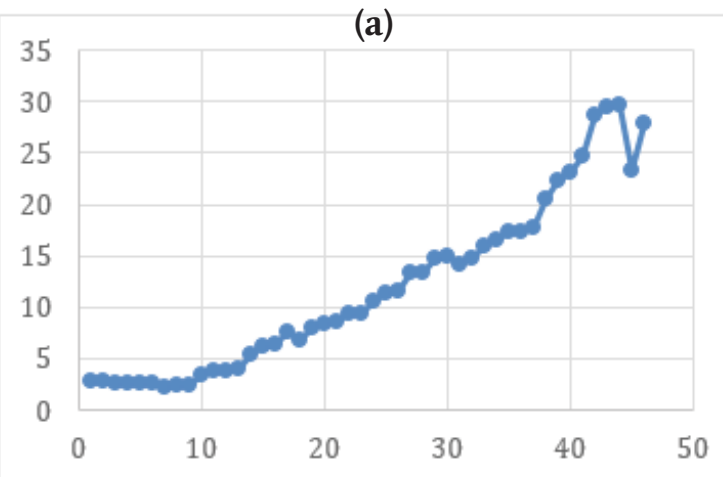

(b)

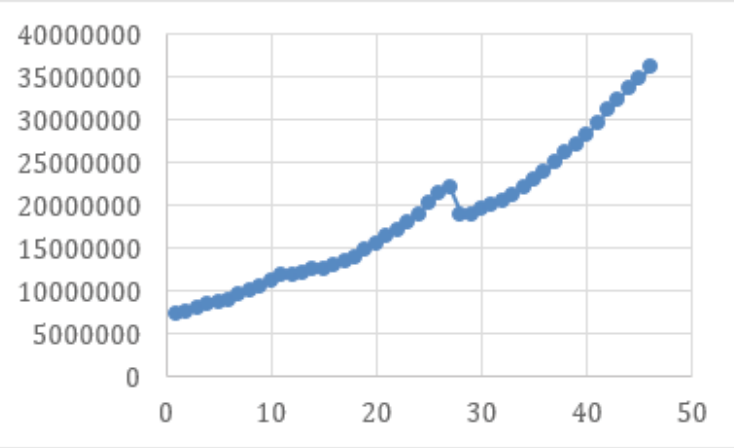

(c)

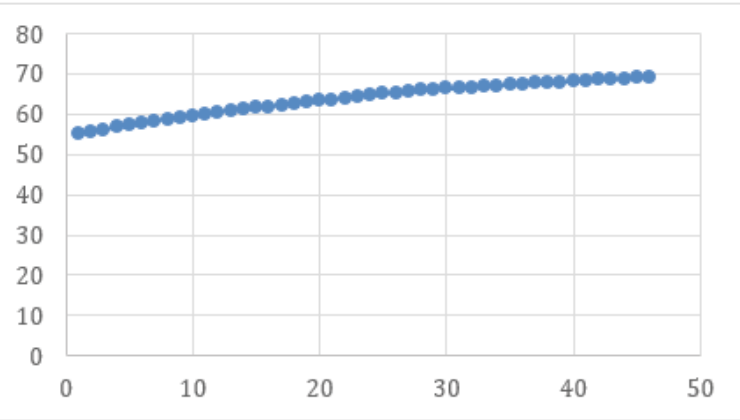

capita fluctuations in 1971-20I6. Indonesia's GDP had always increased from I97I-I997, then in I997-I998 there was a monetary crisis that caused GDP Per capita to decline. GDP of Per capita had increased again from 2000-2016. Then based on Figure 2c, life expectancy in Indonesia had always increased from I97I-2016. Increasing life expectancy shows that health status in Indonesia is increasing. Moreover, it indicated that health development programs and other social programs including environmental health, adequate nutrition, and calories in Indonesia have been successful.

The following is the development of trade openness in Indonesia from I971-20I6.

Figure 3 Trade Openness of Indonesia (I97I2016)

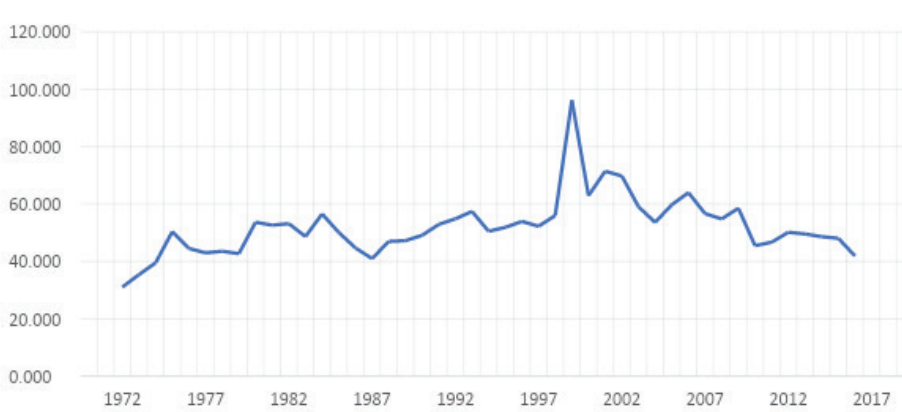

Source: Central Statistics Agency (BPS) 2018

Figure 3 shows the fluctuations in trade openness variable in Indonesia from I97I-20I6. The highest trade openness index occurred in I998, which amounted to 96,I86. However, after that year, trade openness in Indonesia had tended to decline further until 2016. The high number of trade openness in 1998 may had been the impact of Indonesia's joining the world trade organization in 1995 .

After seeing the development of numbers from I97I-20I6 for each variable, then the data normality test was then carried out. Data was said to be normal if it had a p-value $<0.05$. The following was the result of testing the normality of data. 
Table 2 Test of Normality Distribution

\begin{tabular}{|c|c|c|c|c|c|}
\hline & & TO & LE & GDP & SET \\
\hline N & & 46 & 46 & 46 & 46 \\
\hline \multirow{2}{*}{$\begin{array}{l}\text { Normal } \\
\text { Parameters }\end{array}$} & Mean & 51.7130 & 63.6507 & 18417830.09 & 11.9061 \\
\hline & Std. Deviation & 10.54948 & 4.15405 & 7983510.955 & 8.40837 \\
\hline \multicolumn{2}{|c|}{ Kolmogorov-Smirnov Z } & 0.840 & 0.794 & 0.697 & 0.861 \\
\hline \multicolumn{2}{|c|}{ Asymp. Sig. (2-tailed) } & 0.480 & 0.554 & 0.716 & 0.449 \\
\hline
\end{tabular}

Based on Table 2, it could be seen that all variables had a p-value of more than 0.05 . It showed that all variables were not normally distributed. Transforming data to normal data was also not a good solution because it would not be appropriate. For this reason, this study used the SEM-PLS method which was more flexible towards data distribution. SEM-PLS overcame data abnormalities by doing bootstrap resampling with 500 iterations.

\section{Analysis of Trade Globalization Effects on Society's Welfare Using Structural Equation Modelling - Partial Least Square (SEM-PLS)}

PLS had several advantages over covariant-based SEM, including PLS not requiring multivariate normal distribution of data. In addition, PLS could be used for all data scales, not only data with interval or ratio scale (on covariant-based SEM), hence the PLS approach was suitable for use in this study.

Modeling analysis of society's welfare using PLS includes conceptualizing models, making path diagrams, converting path diagrams into system equations, estimating model parameters, evaluating measurement models, evaluating structural models, and testing hypotheses.

\section{Model Conceptualization}

The structure of the model in this study included two latent variables consisting of Trade Globalization $\left(\xi_{2}\right)$ as exogenous variable and Socieety's Welfare $\left(\eta_{T}\right)$ as endogenous variable. It was assumed that $\eta_{I}$ depends on $\xi_{I}$. Mathematical equations could be written as follows.

$$
\eta_{1}=f\left(\xi_{1}\right) \quad x_{1.1}=\Lambda_{x_{1.1}} \xi_{1}+\delta_{1.1}
$$

\section{Construct a Path Diagram}

Since all the measurement models used in this study were models with reflective indicators, the diagram of the path formed was as follows.

Figure 4 Path Diagram of SEM-PLS

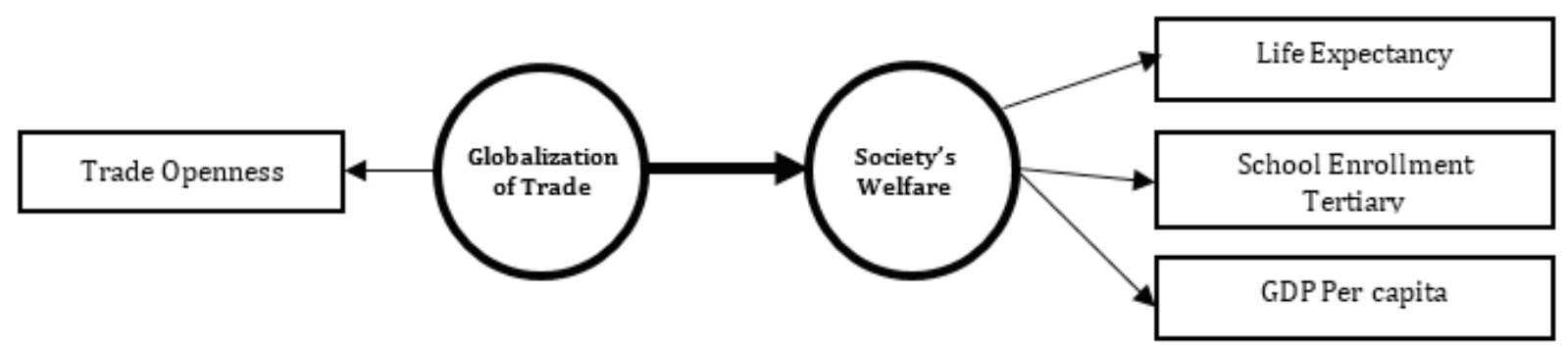

\section{Convert Path Diagram Into Equation System}

\section{Measurement/Outer Model}

The conceptual framework of the study showed a model with a reflexive indicator, so the mathematical equation of measurement model was as follows.

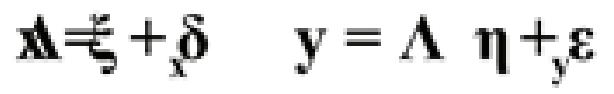


Then, the model was converted into the following mathematical equations.

- Trade globalization Variable ( $(\mathrm{I})$

$x_{1.1}=\Lambda_{x_{1.1}} \xi_{1}+\delta_{1.1}$

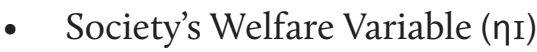

$$
y_{1.1}=\Lambda_{y_{1.1}} \eta_{1}+\varepsilon_{1.1}, \quad y_{1.2}=\Lambda_{y_{1.2}} \eta_{1}+\varepsilon_{1.2}, \quad y_{1.3}=\Lambda_{y_{1.3}} \eta_{1}+\varepsilon_{1.3}
$$

\section{Structural/Inner Model}

It was assumed that latent variables and indicators are standardized with mean values equal to zero and standard deviations equal to one, so that constant parameters could be removed from the model. The structural equation was mathematically written as follows.

$$
\eta_{1}=\gamma_{11} \xi_{1}+\zeta_{1}
$$

\section{Estimation of Model Parameters}

The measurement model parameter coefficients for exogenous and endogenous latent variables is shown in the following table.

Table 2 Estimation of Model Parameters

\begin{tabular}{lll}
\hline Latent Variable & Indicator & $\begin{array}{l}\text { Coeffi- } \\
\text { cient }\end{array}$ \\
\hline $\begin{array}{l}\text { Trade globaliza- } \\
\text { tion }\end{array}$ & Trade Openness & 1.000 \\
\hline \multirow{3}{*}{ Society's Welfare } & \begin{tabular}{l} 
Life Expectancy \\
\cline { 2 - 3 }
\end{tabular} & 0.515 \\
\cline { 2 - 3 } & Sertiary & 0.735 \\
\cline { 2 - 3 } & GDP Per capita & 0.540 \\
\hline
\end{tabular}

The model parameter estimation results in Table 2 shows that all indicators provide positive values for latent variables. This meant that every increase in Trade Openness will reflect the increase in trade globalization in Indonesia. In addition, the parameters of each Society's Welfare indicators were also positive, indicating that any increase in Life Expectancy, School Enrollment and GDP Per capita will also reflect an increase in the welfare of society.
Furthermore, the structural model coefficients obtained are used to form the structural model equations as follows.

$\eta_{1}=-0.490 \xi_{1}+\zeta_{1}$

\section{Evaluation of Measurement/Outer Model}

Evaluation of measurement model involved evaluating the validity of each indicator against its latent variables. The value of loading factors to test the validity is shown in Table 2. Based on coefficient value for each indicator, it could be seen that Trade Openness is a valid indicator in measuring Trade Globalization. While, valid indicator in measuring Society's Welfare is GDP per capita and School Enrollment Tertiary.

\section{Evaluation of Structural/Inner Model}

Evaluation of structural models was used to see the relationship between latent constructs which have been hypothesized before by looking at the results of estimated parameter coefficients and their level of significance. Based on the results of analysis, obtained a moderate $\mathrm{R}^{2}$ value of 0.240 . This showed that variations in Society's Welfare that can be explained by trade globalization were $24 \%$, while the remaining $76 \%$ was explained by other variables outside the model.

\section{Hypothesis Test}

The test of hypothesis in PLS included testing the parameters $\lambda, \beta$, and $\gamma$ which were carried out by the bootstrap resampling method with the number of replications used was $B=500$ resampling. 


\section{Hypothesis Test for Measurement Model}

The hypothesis used was as follows.

$$
\mathrm{H}_{0}: \lambda_{i}=0 \quad \mathrm{H}_{1}: \lambda_{i} \neq 0
$$

The $t_{\text {test }}$ value for measurement model was shown in the following table.

Table 3 Test Statistics for Measurement Models

\begin{tabular}{llll}
\hline Latent Variable & Indicator & $\begin{array}{l}\text { Test Sta- } \\
\text { tistics }\end{array}$ & $\begin{array}{l}\text { P-val- } \\
\text { ues }\end{array}$ \\
\hline $\begin{array}{l}\text { Globalization } \\
\text { of Trade }\end{array}$ & Trade Openness & & \\
\hline & Life Expectancy & 1.261 & 0.219 \\
\cline { 2 - 4 } $\begin{array}{l}\text { Society's Wel- } \\
\text { fare }\end{array}$ & $\begin{array}{l}\text { School Enroll- } \\
\text { ment }\end{array}$ & 1.927 & 0.047 \\
\cline { 2 - 4 } & GDP Per capita & 2.089 & 0.037 \\
\hline
\end{tabular}

Based on Table 3, the test results obtained information that there were several significant $t_{\text {test }}$ values of indicators, namely Trade Openness, School Enrollment and GDP per capita. This fact means that trade globalization measured through Trade Openness can be an accommodation for acquiring new technology from abroad in various fields, such as in education sector to improve the quality of human resources through increasing School Enrollment, in health sector to treat various diseases and reduce risk of death so that life expectancy increases, as well as in economic sector to increase the income per capita of Indonesia's society.

\section{Hypothesis Test for Structural Model}

Hypothesis used to test the structural model was the globalization of trade affecting society's welfare.

$\mathrm{H}_{0}: \gamma_{11}=0 \quad \mathrm{H}_{1}: \gamma_{11} \neq 0$

The $t_{\text {test }}$ test results were shown in the following table.

Table 4 Test Statistics for Structural Model

\begin{tabular}{lllll}
\hline & $\begin{array}{l}\text { Original } \\
\text { Sample }\end{array}$ & $\begin{array}{l}\text { Standard } \\
\text { Error }\end{array}$ & T Statistics & P Values \\
\hline TG SW & -0.490 & 0.260 & 1.885 & 0.060 \\
\hline
\end{tabular}

Based on Table 4, the p-value o,o6o is less than $\alpha$ o.Io (significant), showing that Trade
Globalization has a negative and significant influence on the Society's Welfare and the magnitude of influence is 0.490 . Mathematically, the structural model of PLS analysis was written as follows.

$$
\eta_{1}=-0.490 \xi_{1}+\zeta_{1}
$$

The model shows that Society's Welfare $(\eta I)$ was influenced by Trade Globalization $\left(\xi_{I}\right)$ of 0.490 (significant). That is, if Trade Globalization increases by one unit, then the Society's Welfare will decrease by 0.490 units and vice versa.

In the economic aspect, trade globalization positively enabled people from various countries to import more goods from abroad so that consumers have more choices of goods with better quality and lower prices. But negatively, globalization could also worsen the trade balance, because it tends to increase imported goods. In addition, if the country is unable to compete, exports will also not develop.

The trade balance was the net difference between the export value of a country and the import of merchandise, with exports listed on the asset side on the liability side. The trade balance was said to be a surplus if exports exceed imports, while deficits were said if imports exceed exports. If imports were greater than exports, the trade balance would be worse or deficit. This was caused when import was bigger than export. It would cause consumption prices to rise and would result in a weakening exchange rate (rupiah), and then inflation occurred. On the other hand, the existence of globalization would make prices cheaper. But if we kept importing in the long run, it would undermine the country's wealth because we have to pay more to other parties, while the income was minimal. This then made the state a loss.

Another adverse effect was net income from abroad production factors tends to experience a deficit as well as an increase in foreign investment which will make the flow of payments to increase investment income abroad. In short term, this will cause the country's economic growth to become unstable, 
which in the long term will reduce the rate of economic growth which is marked by a decline in GDP Per capita (Minarsih, 20I7).

In health aspect, globalization of trade causes changes in activities, including:

I. Consumption Abroad, is a health service in another country, because of good service or cheaper treatment. The negative impact of this activity is that people will abandon alternative medical methods so that many mobility of health consumers (patients) go abroad to seek treatment or obtain medical care.

2. Cross Border Trade, is a health service transaction that allows doctors and patients to meet indirectly, in other sense, trade products can be consumed without the need to visit the service producing country.

3. Commercial Presence, is the hospitals or health providers with foreign ownership. The positive impact of this activity is that the quality of health services in Indonesia will be better because of collaboration between the government and the private sector. This activity also have a negative impact by shifting public sector doctors to the private sector because of higher salary and allowance. It causes the inequality on medical personnel, which in the long term will cause the health system to be controlled by the private sector and market prices, so that health costs become more expensive and can only be accessed by the upper middle class.

4. Appearance of Natural Presence, is a trade in services organized by foreign workers in a country.

In education aspect, globalization of trade allows the entry of new technologies which facilitate the learning system. In addition, more reference in terms of learning is available so students can easily access quality education information and learning materials. The existence of trade globalization also provides an opportunity for Indonesian students to study in foreign education institutions. Nevertheless, globalization of trade has a negative impact, including the decline in student moral quality because information on the internet can be accessed freely by anyone, so that students' morale will be affected by the content that is read or watched on these media. In addition, the advancement of information technology in the world of education will also cause social inequality, because the technology can only be enjoyed by schools in urban areas, while schools in the interior will experience lags due to difficulties in access and lack of capital.

The results of this study are in line with the research by Bashar and Khan (2007) which showed the ineffectiveness of trade globalization on economic growth, even globalization of trade had a negative effect on economic growth which is one indicator in measuring the welfare of society. Arif and Ahmad (20I2) in his research also showed that there was a two-way causality relationship between trade globalization and economic growth. In addition, Aka (2006) in his article "Openness, Globalization and Economic Growth: Empirical Evidence From Cote D'Ivore" concluded that trade globalization had a negative influence on economic growth. This contrasts with the estimates of the WTO regarding the positive impact of trade globalization on economic growth, namely increasing openness in international trade. The findings also contrast with the new growth therapy about the potential long-term effects of trade globalization and economic growth.

\section{CONCLUSION}

In general, the results of partial testing of the measurement model showed that Trade Openness is significant indicator for measuring trade globalization. In addition, School Enrollment and GDP Per capita are also significant indicators in measuring Society's Welfare. For this reason, globalization measured through Trade Openness can also be an accommodation to obtain new technology from abroad in various fields, such as the education sector to improve the quality of human resources through increasing school enrollment rates, the health sector to treat various diseases and reduce the risk of death so that life expectancy increases, as well as the economic sector to increase the income per capita of the Indonesian community. 
The results of PLS testing showed that trade globalization has a negative impact on the welfare of the country. In the economic aspect, trade globalization could worsen the trade balance, because it tends to increase imported goods. In addition, if the country is unable to compete, exports will also not develop. In short term, this will cause the country's economic growth to become unstable, which in the long term will reduce the rate of economic growth which is marked by a decline in GDP per capita. In health aspect, trade globalization causes changes in activities, including consumption abroad, cross border trade, commercial presence, and an appearance of natural presence. Meanwhile, in education aspect, trade globalization has negative impact, including the decline in student moral quality and social inequality.

\section{REFERENCES}

Agusalim, L. dan Pohan, F. S. (2017). Globalisasi ekonomi dan pengaruhnya terhadap kemiskinan dan ketimpangan pendapatan di Indonesia. Dipresentasikan di Konferensi Nasional dan Call for Paper Improving Accounting, Management dan Economic Research in Developing Bussiness Sustainability and Economi Growth.

Aka, Bedia, F. (2006). Openness, Globalization and Economic Growth: Empirical Evidence from Cote D'Ivoire. International Journal of Applied Econometrics and Quantitative Studies, 3(2): $67-85$.

Aliyah, H., \& Indra. (20I7). Dampak Globalisasi Perdagangan terhadap Tingkat Kesejahteraan Negara-negara Berpenduduk Islam. Bisnis dan Manajemen, 7 (I), 99-IIo

Amala, F., \& Heriqbaldi, U. (2015, Agustus 02). Dampak Keterbukaan Perdagangan Internasional Sektor Jasa Terhadap Pertumbuhan Ekonomi : Pendekatan Panel Dinamis. Ekonomi dan Bisnis.

Arif, Asma dan Ahmad Hasnat. (2012). Impact of Trade Openness On Output Growth: Co Integration and Error Correction Model Approach. International Journal of Economics and Financial Issues, 2(4): 379-385.

Bashar, Omar dan Khan Habibullah. (2007). Liberalization and Growth: An Eeconometric Study of Bangladesh. Working Paper, U2I Global, Malaysia, February.
Borchert, I., \& Yotov, Y. Y. (20I7). Distance, Globalization, and International Trade. Economics Letter, 32-38.

Chin, W. W. (1998). The Partial Least Squares Approach to Structural Equation Modelling. Modelling Methods for Bussiness Research, 295(2), 295-336.

Diputra, B. T. (20I7). Pengaruh Keterbukaan Ekonomi Terhadap Indeks Pembangunan Manusia di Indonesia di Tahun 2000-2015. Departemen Ilmu Ekonomi Fakultas Ekonomi dan Bisnis Universitas Hasanuddin Makasar.

Fakih, M. (2002). Runtuhnya Teori Pembangunan dan Globalisasi. Yogyakarta: Pustaka Pelajar.

Ghozali, I. H., \& Fuad. (2005). Structural Equation Modelling : Teori, Konsep, dan Aplikasi. Semarang: Badan Penerbit Universitas Diponegoro.

Mahesh, M. (2016). The Effects of Trade Openness on Income Inequality - Evidence from BRIC Countries. Economics Bulletin, 36(3): I75I-I76I.

Minarsih, Maria M. (20I7). Kebijakan Ekonomi Indonesia dan Internasional Serta Tantangannya Di Era Globalisasi. Jurnal Manajemen Universitas Pandanaran.

Mutascu, M., dan Fleischer, A. (20II). Economic Growth and Globalization in Romania. World Applied Science Journal I2 (I0): I69I-I697, $20 I I$.

Nawatmi, S. (20II). Globalisasi dan Inflasi Globalization and Inflation. Dinamika Keuangan dan Perbankan, 3, 88-Ior.

Okungbowa, F.O.E., dan Eburajolo, O.C. (2014). Globalization and Poverty Rate in Nigeria: An empirical Analysis. International Journal of Humanities and Social Science, 4(II): I26-I35.

Ogunyomi, O.O., Daisi, O.R., dan Oluwashikemi, R.A. (20I3). Economic Globalization, Income Inequality and Economic Growth In Nigeria: A Static Data Analysis (1986-2010). ABC Journal of Advanced Research, 2(2): 55-68.

Ravallion, M. (2006), Looking Beyond Averages In the Trade and Poverty Debate. World Development, Elsevier, 34(8): I374-I392. Available from: http://dx.doi.org /Io.Ior6/j. worlddev.2005.I0.015.

Rifqi, M. (2013). Dampak Globalisasi Perdagangan antara ASEAN-5 dan China.

Salim, K., \& Sari, M. P. (20I4, Desember). Pengaruh Globalisasi terhadap Dunia Pendidikan.

Salimi, F., Akhoondzadeh, T., dan Arsalanbod, M. R. (20I4). The triangle of trade liberalization, economic growth and income inequality. Communications on Advanced Computational 
Science with Applications, 20I4(I): I-I5. http p://doi.org /I0.5899/20I4/cacsa-00026.

Suprijanto, A. (20II). Dampak globalisasi ekonomi terhadap perekonomian Indonesia. Jurnal Ilmiah CIVIS, I(2).

Wong, M.Y.H. (20I6). Globalization, spending and income inequality in Asia Pasific. Journal of Comparative Asian Development, I5(I): I-I8. http p://dx.doi.org/Io.Io8o/I5339II4.20I5.III5746.

Wijayanto, S. H. (2008). Structural Equation Modelling dengan LISREL 8.8. Yogyakarta: Graha Ilmu.

Zakaria, M., dan Fida, B.A. (20I6). Trade Openness and income inequality in China and the SAARC Region, Asian Pasific Economic Literature, 30(2): 33-44. htt p://doi.org/IO. IIII/apel.I2I52. 
